\title{
COMMENT
}

EVOLUTION Reflections on a best-seller, The Selfish Gene, at 40 p.462
HISTORY Mathematics was once mystical and practical $\mathbf{p . 4 6 4}$
COMMunity Concerns grow for Turkey's academics prosecuted by the state $\mathbf{p . 4 6 6}$
EMISSIONS A call to hold the atmosphere in trust and claim for damages $\mathbf{p . 4 6 6}$
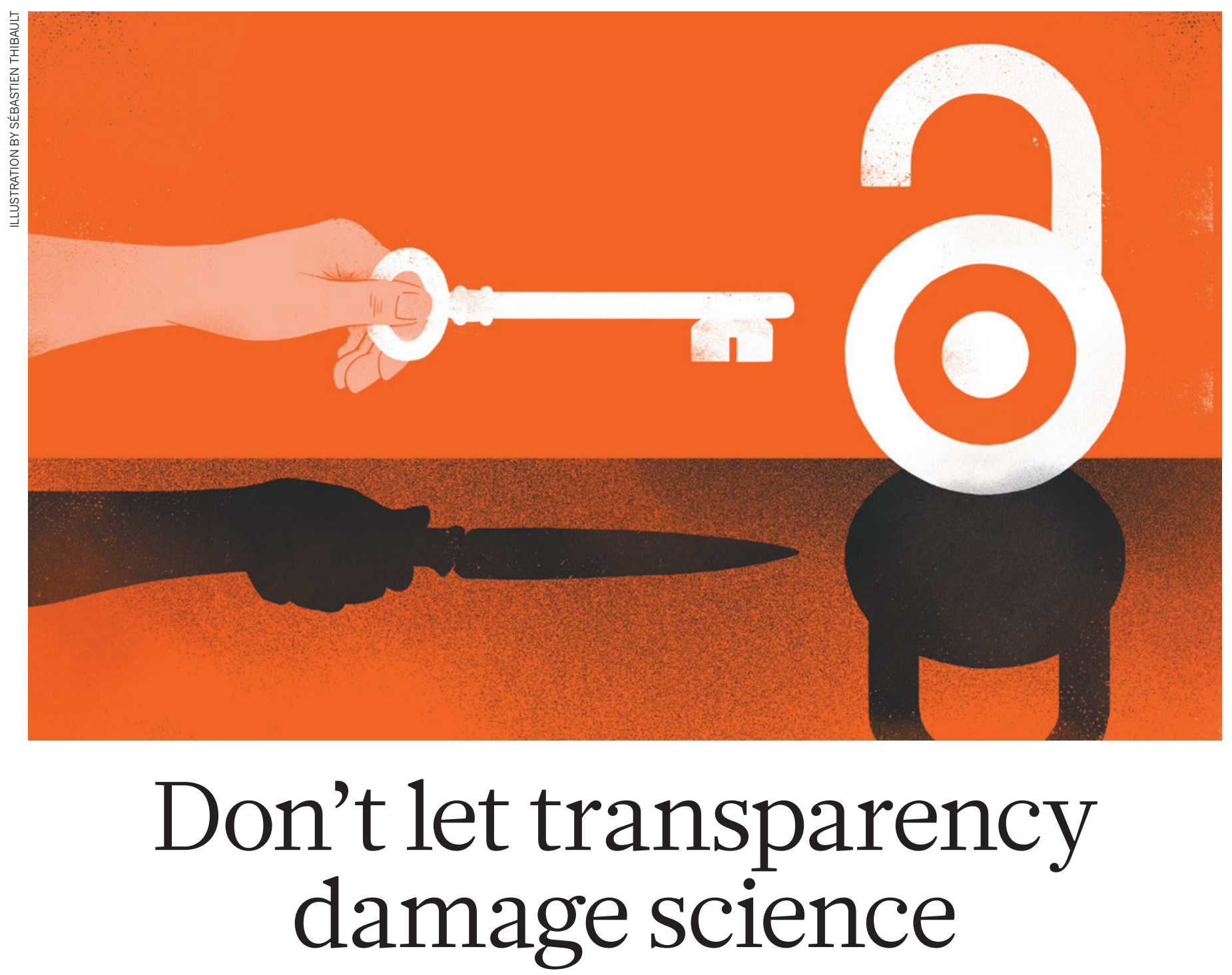

Stephan Lewandowsky and Dorothy Bishop explain how the research community should protect its members from harassment, while encouraging the openness that has become essential to science.

$\mathrm{T}$ ransparency has hit the headlines. In the wake of evidence that many research findings are not reproducible $^{1}$, the scientific community has launched initiatives to increase data sharing, transparency and open critique. As with any new development, there are unintended consequences. Many measures that can improve science $^{2}-$ shared data, post-publication peer review and public engagement on social media - can be turned against scientists.

Endless information requests, complaints to researchers' universities, online harassment, distortion of scientific findings and even threats of violence: these were all recurring experiences shared by researchers from a broad range of disciplines at a Royal Society-sponsored meeting last year that we organized to explore this topic. Orchestrated and well-funded harassment campaigns against researchers working in climate change and tobacco control are well documented ${ }^{3,4}$. Some hard-line opponents to other research, such as that on nuclear fallout, vaccination, chronic fatigue syndrome or genetically modified organisms, although less resourced, have employed identical strategies. 
> Such attacks place scientists in a difficult position. Good researchers do not turn away when confronted by alternative views. However, their openness can be exploited by opponents who are keen to stall inconvenient research. When people object to science because it challenges their beliefs or jeopardizes their interests, they are rarely committed to informed debate.

The progress of research demands transparency. But as scientists work to boost rigour, they risk making science more vulnerable to attacks. Awareness of tactics is paramount. Here, we describe ways to distinguish scrutiny from harassment.

\section{USE AND ABUSE}

We have identified ten red-flag areas that can help to differentiate healthy debate, problematic research practices and campaigns that masquerade as scientific inquiry (see 'Ten red flags'). None by itself is conclusive, but a preponderance of troubling signs can help to steer the responses of scientists and their institutions to criticism.

We also examine five legitimate tools of scholarly exchange, how they can be 'weaponized' (see 'Five doubled-edged tools' for a summary) and how to protect openness while curtailing its abuse.

Calls for open data: checking versus undermining. Many organized attacks call for more data, often with the aim of finding an analysis method that makes undesirable results go away ${ }^{5}$. The tobacco industry sponsored and drafted US legislation to enhance access to data on tobacco research, with the intention to delay or prevent evidence-based publichealth measures ${ }^{6}$. Calls for more data can also be used to create the false impression that data are being withheld. In October last year, the chair of the Committee on Science, Space, and Technology of the US House of Representatives, a long-term critic of climate scientists, subpoenaed data from a federal agency that were already publicly available on the Internet (see go.nature.com/p4tmjd).

Protective action. We strongly support open data ${ }^{7}$, and scientists should not regard all requests for data as harassment.

When researchers cannot share data, they should explain why. Valid reasons may include confidentiality issues with clinical data, and cases in which participants' consent did not explicitly encompass data sharing. Researchers also need control over how data is to be used if it goes beyond what participants agreed to (for example, analysis of ethnic, race or gender differences in data collected for different purposes). The status of data availability should be enshrined in the publication record along with details about what information has been withheld and why. Some journals and publishers are already moving towards this practice (for example,

\section{TEN RED FLAGS}

Dr A publishes a study showing that food $X$ increases the risk of disease $Y$. Critics accuse her of incompetence, scaremongering and ethical violations. Do these accusations constitute harassment or healthy debate?

\begin{tabular}{|c|c|}
\hline & Raises red flags about researcher \\
\hline Expertise & $\begin{array}{l}\text { Does Dr A's contested work fall outside } \\
\text { her training or her previous publications? }\end{array}$ \\
\hline Conflicts & $\begin{array}{l}\text { Is Dr A funded by competitors of } X \text { ? Is she } \\
\text { marketing an antidote for } Y \text { ? }\end{array}$ \\
\hline Communication & $\begin{array}{l}\text { Did Dr A promote this work without } \\
\text { publishing it in a peer-reviewed journal? }\end{array}$ \\
\hline Errors & $\begin{array}{l}\text { Does Dr A have a track record of major } \\
\text { errors? Has she been defensive about } \\
\text { minor errors? }\end{array}$ \\
\hline Balance & $\begin{array}{l}\text { Does Dr A have a record of } \\
\text { misrepresenting evidence? Does she } \\
\text { dismiss counter-arguments? }\end{array}$ \\
\hline Scholarship & $\begin{array}{l}\text { Are results out of line with existing, } \\
\text { reputable scholarship, if it exists? }\end{array}$ \\
\hline Transparency & $\begin{array}{l}\text { Has Dr A refused to make data available? } \\
\text { Has she ignored reasonable disclosure } \\
\text { standards? }\end{array}$ \\
\hline Track record & $\begin{array}{l}\text { Has Dr A routinely promoted flashy work } \\
\text { without peer review? }\end{array}$ \\
\hline Insults or libel & $\begin{array}{l}\text { Does Dr A uniformly dismiss critics as } \\
\text { ignorant, biased or conflicted? }\end{array}$ \\
\hline $\begin{array}{l}\text { Freedom-of- } \\
\text { information } \\
\text { requests }\end{array}$ & $\begin{array}{l}\text { Does Dr A claim that funding sources are } \\
\text { irrelevant? Has she erected barricades to } \\
\text { disclosure? }\end{array}$ \\
\hline
\end{tabular}

\section{Raises red flags about critics}

Are the critics operating outside their area of apparent expertise? Do the critics refuse to engage with the peer-reviewed literature?

Do the critics have a financial interest in the results?

Do the critics attack all researchers who show that $X$ is harmful?

Do the critics use small errors to dismiss all of Dr A's work?

Do the critics have a record of cherrypicking evidence in public statements?

Can the critics specify what they would regard as convincing evidence?

Are the critics making showy demands for already-public data, or for data for which patients have not consented to publication?

Do the critics attack scientists across disciplines on different topics? Do they have a track record of harassment or vexatious complaints?

Are the critics levelling personal attacks? Are criticisms from anonymous sources or 'sock puppets'?

Do the critics use freedom-of-information requests for private correspondence unrelated to funding?

PLOS and some journals published by the Association for Psychological Science, including Psychological Science). Calls for a data set that ignore its open availability (including limitations agreed on during publication, where applicable) could suggest harassment.

We suspect that explicit discussion of what data are and are not available as part of the original publication process might have averted some of the ongoing controversy surrounding the PACE clinical trial, a UK study on chronic fatigue syndrome. The issue involves requests for data by transparency advocates, and the refusal by researchers and institutions to release data citing patient confidentiality, limited consent and requestors' intent.

Even when data availability is described in papers, tension may still arise if researchers do not trust the good faith of those requesting data, and if they suspect that requestors will cherry-pick data to discredit reasonable conclusions. Research is already moving towards study 'pre-registration' (researchers publishing their intended method and analysis plans before starting) as a way to avoid bias, and the same strictures should apply to critics during reanalysis. In general, critics and original researchers should obey symmetrical standards of openness and responsibility and be subject to symmetrical scrutiny concerning conflicts of interest ${ }^{8}$. In cases in which researchers have no confidence in the good faith of the people requesting data, one potential solution would be arbitration by an independent adjudicator.

Social media: rapid correction versus mob rule. Blogs and social media enable rapid correction of science by scientists, as shown by the 'arsenic life' controversy in 2012, in which initial claims of a startling finding - that a bacterium could survive without phosphorus by substituting arsenic in its place in essential biomolecules - were rapidly rebutted by experts online (see Nature http://doi.org/ fx24wg; 2012). Yet social media and online comments also offer an easy way to inject biased, incorrect or misleading information. And because engagement with critics is a core element of scientific practice, researchers may feel obliged to respond even to 'trolls' (online harassers).

Protective action. Scientists should ignore critics who are abusive or illogical and those that make the same points repeatedly despite rebuttals. Internet trolling has been associated with sadism and psychopathy ${ }^{9}$. Engagement with such bad-faith actors can imperil scientists' well-being in a way that university ethics committees would never condone in research on human subjects. 
All who participate in post-publication review should identify themselves. The drawbacks of anonymity (its encouragement of bad behaviour) outweigh its advantages (for example, it allows junior people to criticize senior academics without fear of redress). What's more, the scientific community should not indulge in games of 'gotcha' (intentionally turning small errors against a person). Minor corrections and clarifications after publication should not be a reason to stigmatize fellow researchers. Scientific publications should be seen as 'living documents', with corrigenda an accepted - if unwelcome - part of scientific progress.

Freedom-of-information requests: right to know versus right to privacy. Freedomof-information (FOI) requests have revealed conflicts of interest, including undisclosed funding of scientists by corporate interests such as pharmaceutical companies and utilities. But information requests have also been used as harassment, in attempts to embarrass researchers or just to waste their time. In 2010, the then-attorney-general of Virginia sought to obtain private e-mail correspondence from climate scientist Michael Mann, relating to work undertaken while he was at the University of Virginia in Charlottesville. This request, widely seen as a witch-hunt (see Nature 465, 135-136; 2010), was ultimately struck down by the Virginia high court.

Protective action. Given that contemporary conversations are mainly conducted by e-mail, broad-ranging FOI laws risk being tantamount to permanent wiretaps in academics' offices. We fear that without the guarantee of privacy during e-mail conversations, self-censorship will have chilling effects on academic freedom and incisive discussion. A 2013 decision of the UK information commissioner towards preserving researchers' rights against disclosing "material which is still in the course of completion, to unfinished documents or to incomplete data" are encouraging, and cogent guidelines are beginning to emerge.

However, the right to privacy should not extend to funding arrangements ${ }^{10}$. Researchers should scrupulously disclose all sources of

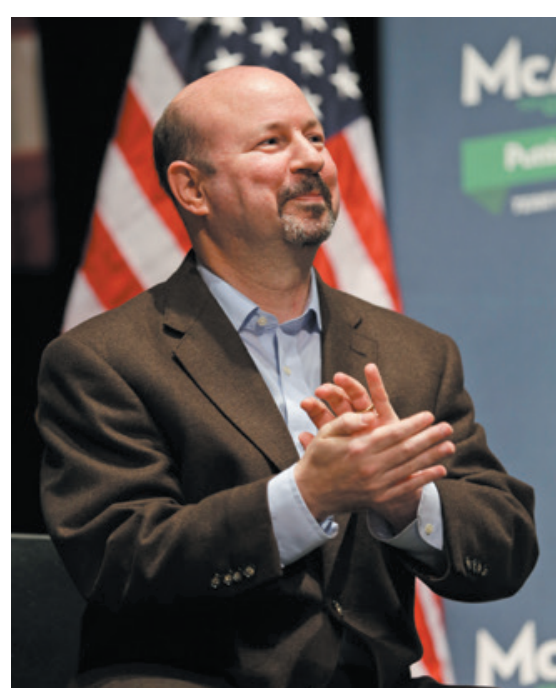

Climate scientist Michael Mann was hounded for private e-mails.

funding; even small undisclosed amounts can create an impression of undue influence, as in a 2015 case involving a US researcher who was working on genetically modified crops and had received US $\$ 25,000$ from Monsanto to assist his outreach efforts (see Nature 524, 145-146; 2015). FOI requests can be an appropriate tool in cases involving the conflation of public money and private interests.

\section{Calls for retraction: correction versus} censorship. Publication retractions have historically been reserved for cases of fraud or grave errors. Increasingly, however, calls for retraction are coming from people who do not like a paper's conclusions. In one famous case, a committee created by the National Football League called for a journal to retract an article by a medical researcher who argued that severe brain damage in a deceased American-football player had probably resulted from repeated concussions. (These conclusions were eventually endorsed by independent researchers.)

Protective action. Journals and professional societies should condemn specious calls for retraction. Journals and institutions can also publish threats of litigation, and use sunlight as a disinfectant.

\begin{tabular}{|c|c|c|}
\hline \multicolumn{3}{|c|}{$\begin{array}{l}\text { FIVE DOUBLE-EDGED TOOLS } \\
\text { Legitimate tools of scholarly exchange can be weaponized. }\end{array}$} \\
\hline Technique & Use & Abuse \\
\hline Call for data & $\begin{array}{l}\text { Permit the replication or inspection of } \\
\text { analyses. }\end{array}$ & $\begin{array}{l}\text { Impugn scientists' integrity (when } \\
\text { data is already available); biased } \\
\text { re-analyses. }\end{array}$ \\
\hline Social-media posts & $\begin{array}{l}\text { Highlight errors or questionable } \\
\text { practices. }\end{array}$ & Stalk, libel, intimidate or harass. \\
\hline $\begin{array}{l}\text { Freedom-of-information } \\
\text { requests }\end{array}$ & Reveal hidden conflicts of interest. & $\begin{array}{l}\text { Launch a fishing expedition into } \\
\text { private correspondence. }\end{array}$ \\
\hline Call for retraction & $\begin{array}{l}\text { Remove unethical or erroneous work } \\
\text { from the literature. }\end{array}$ & Discredit inconvenient results. \\
\hline Complaints to universities & Redress unethical conduct. & Damage reputation. \\
\hline
\end{tabular}

Institutional self-scrutiny versus protection from harassment. Universities have complaint processes for good reasons. However, complaints are also used to undermine researchers doing legitimate but controversial science ${ }^{3}$.

Protective action. Scientists who are harassed often feel alone. Universities do not tolerate harassment based on race or gender, and neither should they tolerate harassment based on contentious science. They should provide training and support to help their researchers cope. Public declarations can be particularly useful: in 2014, in response to the harassment of one of its professors, the Rochester Institute of Technology in New York publicly acknowledged the scientific consensus on climate change and its support for academic freedom.

\section{NEXT STEPS}

Numerous professional bodies, educational institutions, government agencies and journals have convened meetings during the past few years to put science under the microscope. Issues such as reproducibility and conflicts of interest have legitimately attracted much scrutiny and have stimulated corrective action. As a result, the field is being invigorated by initiatives such as study pre-registration and open data.

Similar attention must be devoted to stressors and threats to science that arise in response to research that is considered inconvenient. The same institutions and bodies that have scrutinized science must also start a conversation about how to protect it.

Stephan Lewandowsky is professor in cognitive psychology at the University of Bristol, UK, who focuses on the public understanding of science. Dorothy Bishop is professor of developmental neuropsychology at the University of Oxford, UK; she chaired a symposium at the Wellcome Trust in London in April 2015 on improving scientific reliability.

e-mails: stephan.lewandowsky@bristol.ac.uk; dorothy.bishop@psy.ox.ac.uk

1. Nosek, B. A. et al. Science 348, 1422-1425 (2015).

2. Alberts, B. et al. Science $348,1420-1422$ (2015)

3. Landman, A. \& Glantz, S. A. Am. J. Public Health 99, 45-58 (2009)

4. Lewandowsky, S., Mann, M. E., Bauld, L., Hastings, G. \& Loftus, E. F. 'The subterranean war on science’ APS Observer (2013); available at http:// go.nature.com/iqtjsp

5. Cataldo, J. K., Bero, L. A. \& Malone, R. E. J. Clin. Epidemiol. 63, 841-853 (2010).

6. Baba, A., Cook, D. M., McGarity, T. O. \& Bero, L. A. Am. J. Pub. Health 95, S20-S27 (2005).

7. Morey, R. D. et al. R. Soc. Open Sci. 2, 15047 (2015).

8. Christakis, D. A. \& Zimmerman, F. J. J. Am. Med. Assoc. 310, 2499-2500 (2013).

9. Buckels, E. E., Trapnell, P. D. \& Paulhus, D. L. Personal. Individ. Diff. 67, 97-102 (2014)

10.Oreskes, N., Carlat, D., Mann, M. E., Thacker, P. D. \& vom Saal, F. S. Environ. Sci. Technol. 49, 7527-7528 (2015) 